\title{
PRIHODI I TROŠKOVI PROIZVODNJE U ŠUMARSTVU FEDERACIJE BOSNE I HERCEGOVINE*
}

\section{Revenues and costs of forestry production in Federation of Bosnia \& Herzegovina}

\author{
Sabina Delić ${ }^{1}$, Mersudin Avdibegović ${ }^{1}$
}

\begin{abstract}
This paper deals with the revenues analyses realized in B-H Forest Management Companies (FMCs) as well as the structure of related production costs. As the revenues of FMCs come mainly from wood assortments production, the achieved prices and quality structure of felling are prevailing factors in total revenue generation.

The main goal of this analysis is to point out on different revenues obtaining possibilities caused by various production conditions between individual FMCs. Besides, the costs structure varies among the FMCs due to different human resources circumstances and materially/technically conditions. Thus, the production costs of forest products extremely vary with direct consequences on Forest Management Companies' profitability and their reproductive ability. This follows to different investment capacity of FMCs, first of all in terms of biological reproduction investments. The results of previous research points out on high level on synchronization between the amount of investments in biological reproduction and financial capabilities of FMCs. However, it should correspond to the real needs in concrete situation. This should lead to violation of sustainability principle, as a major principle of forest resources management.
\end{abstract}

Key words: revenue, costs of production, profitability, biological reproduction investment, sustainable forest management

\section{Izvod}

U ovom radu je izvršena analiza prihoda koji se ostvaruju u šumarstvu Federacije BiH po šumarskim preduzećima, te analiza strukture troškova koji se javljaju u poslovanju preduzeća. S obzirom da se prihodi preduzeća uglavnom baziraju na realizovanim

\footnotetext{
${ }^{*}$ Rad je prezentiran na Međunarodnoj konferenciji "Forestry Science Between Economy and Society Demands" održanoj u Sarajevu, oktobra 2008. g

${ }^{1}$ Šumarski fakultet Univerziteta u Sarajevu - Faculty of Forestry University of Sarajevo
} 
drvnim sortimentima, odlučujuću ulogu u njihovom formiranju ima, pored cijena šumskih drvnih sortimenata i kvalitetna struktura etata.

Cilj ove analize jeste da se ukaže na različite mogućnosti sticanja prihoda kao posljedice različitih uslova privređivanja preduzeća.

Pored toga, struktura troškova je različita po pojedinim preduzećima zbog različite zastupljenosti materijalno-tehničkih i ljudskih resursa. Struktura cijene proizvodnje proizvoda šumarstva izrazito varira između preduzeća, što se neminovno odražava na njihovu rentabilnost, a takođe i na njihovu akumulativnu i reproduktivnu sposobnost. Iz toga proizilazi i ekonomska mogućnost realizacije potrebnih investicionih ulaganja, a prije svega bioloških investicija. Ranije analize pokazuje da se obim bioloških investicija usklađuje sa raspoloživim finansijskim mogućnostima preduzeća, a ne prema realnim potrebama u konkretnim situacijama (DELIĆ, 2008). To bi moglo dovesti do narušavanja principa održivosti, kao osnovnog principa gospodarenja šumskim resursima.

Ključne riječi: prihod, troškovi proizvodnje, profitabilnost, investicije u biološku reprodukciju, održivo gospodarenje

\section{UVOD - Introduction}

Šumarstvo predstavlja integralni dio cjelokupne nacionalne proizvodnje, čiji je osnovni zadatak zadovoljenje društvenih potreba za proizvodima od drveta i ostalim proizvodima i uslugama čija je proizvodnja vezana za šumu. To je djelatnost koja gospodari (koristi, obnavlja i upravlja) jednim od najvažnijih prirodnih resursa i koji predstavlja uslov za odvijanje životnih aktivnosti i opstanka čovjeka. Iz ovog proističe značajna uloga šumarstva u privredi jedne zemlje, gdje se ne smije zanemariti da šumarstvo vršeći privrednu aktivnost vrši istovremeno i mnogobrojne druge općekorisne funkcije (ŠAKOVIĆ, 1998).

$\mathrm{S}$ obzirom na multifunkcionalnost šumarstva, mogućnosti sticanja prihoda preduzeća koja gospodare šumskim resursima su velike. I pored toga, prihodi preduzeća šumarstva Federacije $\mathrm{BiH}$ se uglavnom baziraju na realizovanim drvnim sortimentima. Zato su kvalitet etata i cijene šumskih drvnih sortimenata najvažnije uticajne varijable na ukupan prihod preduzeća. Kvalitet etata zavisi od stanja šuma kojima gospodare pojedina preduzeća. Na ovaj faktor se u kratkom roku ne može značajno uticati, osim preko povećanja stepena iskorištenosti etata u što je moguće „vrednije“ sortimente. Cijene šumskih drvnih sortimenata bi trebale biti rezultat odnosa ponude i potražnje za ovim proizvodima u razvijenim tržišnim uslovima. Međutim, u analiziranoj godini realizacija proizvedenih šumskih drvnih sortimenata se uglavnom odvijala prema propisanim cjenovnicima od strane pojedinih preduzeća, uz značajna variranja cijena istih vrsta sortimenata između preduzeća.

Uspješnost poslovanja preduzeća zavisi ne samo od stečenog ukupnog prihoda, nego i od ostvarenih troškova u proizvodnji. Struktura troškova preduzeća 
šumarstva zavisi od prirodnih uslova privređivanja i različitog stepena iskorištenosti ljudskih i materijalno-tehničkih resursa.

Posljedica toga je različit rezultat poslovanja koji se direktno odražava na reproduktivnu sposobnost preduzeća.

\section{CILJEVI RADA I PODRUČJE ISTRAŽIVANJA - The aims of work and research area}

Cilj ove analize jeste da se ukaže na različite mogućnosti sticanja prihoda i ostvarenja troškova kao posljedice nejednakih prirodnih uslova privređivanja preduzeća i različitog stepena zastupljenosti materijalno-tehničkih i ljudskih resursa. Iz toga proizilazi poslovni rezultat i različite mogućnosti pojedinih preduzeća da izvršavaju svoje obaveze prema šumskom resursu, jer se ne nalaze u ravnopravnom položaju. U cilju dokazivanja ovog stava, u radu su urađene analize:

- ukupnog prihoda i njegove strukture, cijena pojedinih šumskih proizvoda i kvalitetne strukture etata,

- strukture troškova poslovanja, te

- analiza poslovnog rezultata.

Istraživanje se odnosi na poslovanje 8 kantonalnih šumskogospodarskih preduzeća (ŠGP) koja egzistiraju na području Federacije (Unsko-sanske šume, Šume TK, ŠGP Zeničko-dobojskog kantona, Bosansko-podrinjske šume, Srednjobosanske šume, ŠGD Ž ZH d.o.o. Posušje, Sarajevo šume, Hercegbosanske šume), te 4 preduzeća u Hercegovačko-neretvanskom kantonu koja su organizacijski samostalna (Šumarstvo Prenj, Šumarstvo Ljuta, Šumarstvo Srednjeneretvansko i HB šume). Za analizu su korišteni zvanični podaci iz Izvještaja o poslovanju preduzeća za 2006. godinu.

\section{REZULTATI ISTRAŽIVANJA - The results of the study}

\subsection{Ukupan prihod i njegova struktura}

Ukupan prihod u šumarstvu Federacije $\mathrm{BiH}$ u 2006. godini je iznosio 182,383 miliona KM, od čega je 79,8 \% ili 145,6 mil. KM ostvareno prodajom šumskih drvnih proizvoda, a preostalih $20,2 \%$ su prihodi ostvareni po drugim osnovama. Dio prihoda po drugim osnovama odnosi se na prihode od realizacije nedrvnih proizvoda, izvršenih usluga, a u nekim preduzećima značajan udio po osnovu korištenja sredstava iz federalnog i kantonalnih budžeta. Struktura prihoda u pojedinim preduzećima jako varira, što je predstavljeno u tabeli 1 . U nekim preduzećima je zastupljenost prihoda po osnovu prodaje drvnih sortimenata $50 \%$, dok je kod drugih taj procenat čak i $97 \%$.

Ovaj odnos i struktura prihoda ukazuje da šumarstvo svoj prihod uglavnom bazira na šumskim drvnim sortimentima. Naše šume su bogata nalazišta različitih nedrvnih proizvoda, ali, nažalost, preduzeća ne koriste ovu mogućnost kako bi povećala svoje prihode. S obzirom na to, cijene šumskih drvnih sortimenata, kao i 
kvalitetna struktura etata, imaju odlučujuću ulogu u formiranju ukupnog prihoda šumarstva.

Tabela 1. Struktura ostvarenog ukupnog prihoda u 2006. godini

Table 1. Structure of realised revenues, 2006.

\begin{tabular}{|c|c|c|c|c|c|}
\hline \multirow{3}{*}{$\begin{array}{l}\text { ŠUMSKOGOSPODARSKO } \\
\text { PREDUZEĆE }\end{array}$} & \multicolumn{5}{|c|}{ Struktura ukupnog prihoda } \\
\hline & \multicolumn{2}{|c|}{ Prihod od drveta } & \multicolumn{2}{|c|}{ Ostali prihodi } & \multirow{2}{*}{$\begin{array}{c}\begin{array}{c}\text { Ukupan } \\
\text { prihod }\end{array} \\
\text { KM }\end{array}$} \\
\hline & KM & $\%$ & KM & $\%$ & \\
\hline Unsko-sanske šume & 28.141 .582 & 78.04 & 7.916 .822 & 21.96 & 36.058 .404 \\
\hline Šume TK & 13.594 .376 & 83.01 & 2.781 .793 & 16.99 & 16.376 .169 \\
\hline ŠGP ZE-DO kantona & 28.095 .946 & 82.83 & 5.823 .753 & 17.17 & 33.919 .699 \\
\hline Bosansko-podrinjske šume & 1.062 .422 & 79.12 & 280.301 & 20.88 & 1.342 .723 \\
\hline Srednjobosanske šume & 26.819 .828 & 76.34 & 8.311 .875 & 23.66 & 35.131 .703 \\
\hline Šumarstvo "Prenj" Konjic & 4.043 .816 & 87.13 & 597.543 & 12.87 & 4.641 .359 \\
\hline Šmarstvo "Ljuta" & 537.508 & 50.31 & 530.798 & 49.69 & 1.068 .306 \\
\hline $\begin{array}{l}\text { Šumarstvo } \\
\text { "Srednjeneretvansko" }\end{array}$ & 635.043 & 68.61 & 290.509 & 31.39 & 925.552 \\
\hline HB šume & 522.718 & 50.59 & 510.528 & 49.41 & 1.033 .246 \\
\hline Z ZH d.o.o.Posušje & 382.206 & 67.65 & 182.804 & 32.35 & 565.010 \\
\hline Sarajevo-šume & 11.767 .388 & 57.68 & 8.633 .825 & 42.32 & 20.401 .213 \\
\hline Hercegbosanske šume & 29.997 .021 & 97.01 & 922.983 & 2.99 & 30.920 .004 \\
\hline FEDERACIJA BIH & 145.599 .854 & 79.83 & 36.783 .534 & 20.17 & 182.383 .388 \\
\hline
\end{tabular}

Izvor: Izvještaji o poslovanju preduzeća za period januar-decembar 2006. godine

\subsubsection{Analiza cijena šumskih drvnih proizvoda}

Prema raspoloživim informacijama šumski drvni proizvodi četinara i lišćara su uglavnom realizovani po cijenama koje su propisane cjenovnikom na nivou preduzeća. Samo u nekim preduzećima bila je zastupljena prodaja putem licitacije, ali se radi o prodaji malih količina drvnih sortimenata. Prosječne cijene pojedinih sortimenata četinara i lišćara u Federaciji $\mathrm{BiH}$ se mogu vidjeti iz grafikona 1 i 2 . Uočava se da cijene istih drvnih sortimenata variraju između pojedinih preduzeća. Metodika izrade minimalnih cjenovnika u preduzećima nije poznata, ali se može pretpostaviti da se radi o iskustvenim podacima. Tako je, npr., prosječna cijena F trupaca četinara na nivou Federacije $\mathrm{BiH} 177,8 \mathrm{KM} / \mathrm{m}^{3}$, a varira u rasponu od 130 do $351 \mathrm{KM} / \mathrm{m}^{3}$. I kod ostalih sortimanata se javljaju veliki rasponi u cijenama; trupci za rezanje I klase četinara $1: 1,4$, trupci za rezanje II klase 1:1,51, F trupci bukve 1:2,5, F trupci plemenitih lišćara $1: 1,9$, a takođe i cijene manje vrijednih sortimenata (celuloza četinara i lišćara) variraju i imaju raspon od 1:1,5. 


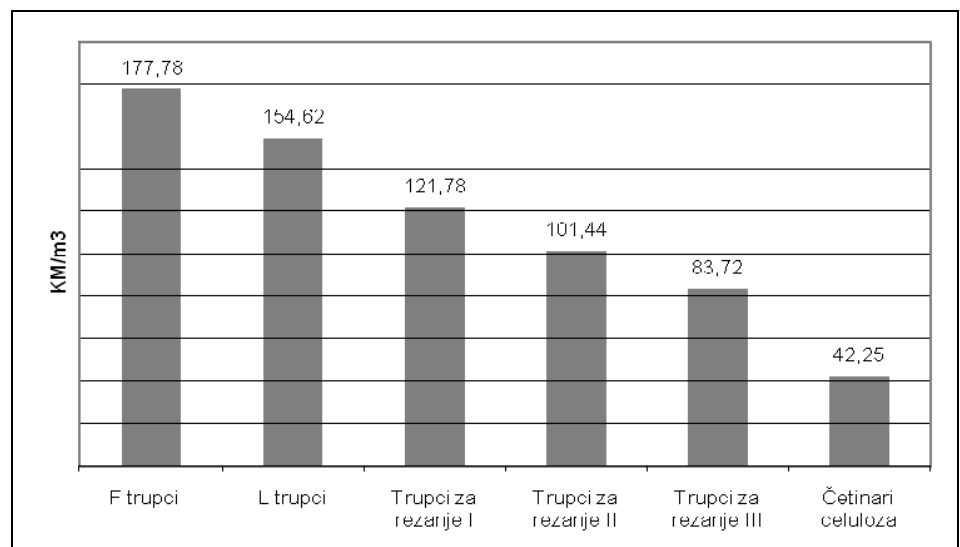

Grafikon 1. Prosječne cijene četinara u Federaciji BiH u 2006.g. Graph 1. Average prices of conifers in Federation of B\&H, 2006.

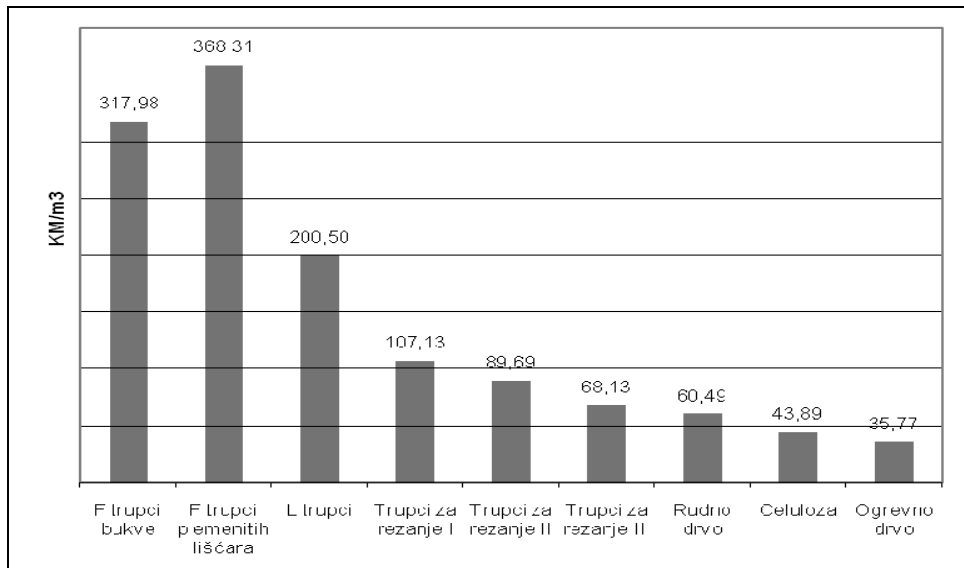

Grafikon 2. Prosječne cijene lišćara u Federaciji BiH u 2006.g.

Graph 2. Average prices of broadleaved in Federation of B\&H, 2006.

\subsubsection{Kvalitetna struktura etata}

Jedan od pokazatelja za ocjenu kvalitetne strukture etata je i ostvareni prihod od etata sveden na jedinicu površine sa koje je realizovan etat (Delić, 2006). Prosječna vrijednost ovog pokazatelja na nivou Federacije BiH iznosi 184,2 KM/ha, a posmatrano po preduzećima varira od 25 do $267 \mathrm{KM} /$ ha (tabela 2). To ukazuje na uticaj različitih prirodnih uslova, a prije svega kvaliteta staništa na kvalitetnu strukturu etata iz koje se realizuje prihod. Kvalitet realizovanog etata direktno utiče na asortiman šumskih drvnih proizvoda i na ostareni prihod. 
Tabela 2. Pokazatelj kvaliteta etata

Table 2. Index of feeling volume quality

\begin{tabular}{|l|c|}
\hline \multicolumn{1}{|c|}{$\begin{array}{c}\text { ŠUMSKOGOSPODARSKO } \\
\text { PREDUZEĆE }\end{array}$} & $\begin{array}{c}\text { Prihod od } \\
\text { etata } \\
\text { KM/ha }\end{array}$ \\
\hline \hline Unsko-sanske šume & 217,70 \\
\hline Šume TK & 253,43 \\
\hline ŠGP ZE-DO kantona & 183,54 \\
\hline Bosansko-podrinjske šume & 59,26 \\
\hline Srednjobosanske šume & 196,62 \\
\hline Hercegovačko-neretvanski kanton & 44,45 \\
\hline Ž ZH d.o.o.Posušje & 24,96 \\
\hline Sarajevo-šume & 267,23 \\
\hline Hercegbosanske šume & 200,08 \\
\hline FEDERACIJA BIH & 184,17 \\
\hline \hline
\end{tabular}

Pored ovog, kao izvedeni pokazatelj kvaliteta etata može poslužiti koeficijent kvaliteta etata. On pokazuje potencijalnu vrijednost prihoda od etata pod pretpostavkom da cjelokupnu količinu etata čine pilanski trupci (MARTINIĆ, 1996).

Prema ovom autoru, koeficijent kvaliteta etata se računa posebno za lišćare i četinare prema obrazcu:

$$
K_{k e}=\frac{U P_{e}}{Q_{n} \cdot C_{t r}}
$$

gdje je:

$K_{k e} \quad \ldots \ldots$. koeficijent kvaliteta etata

$U P_{e} \quad \ldots$. ukupan prihod od etata

$Q_{n} \ldots \ldots$ ukupna neto masa svih sortimenata

$C_{t r} \ldots \ldots$ cijena trupaca za rezanje (prosječna)

Ako je $K_{k e}=1$, znači da je postignuta kvalitetna struktura etata jednaka kvalitetu pilanskih trupaca. Iako se u praksi nikada ne postiže ova pretpostavljena vrijednost, izračunati koeficijent ukazuje na kvalitet realizovanog etata. Što je vrijednost koeficijenta bliža jedinici, radi se o boljem kvalitetu etata i obrnuto.

\subsection{Struktura troškova poslovanja preduzeća}

U cilju utvrđivanja poslovnog rezultata preduzeća izvršena je analiza ostvarenih troškova po pojedinim preduzećima i na nivou šumarstva Federacije BiH. Ukupni troškovi poslovanja svih preduzeća u 2006. godini iznosili su 179,67 miliona KM sa sljedećom strukturom (grafikon 3): 
- $39 \%$ troškovi radne snage

$-4,7 \%$ amortizacija

- $10,2 \%$ materijalni troškovi

- 46,2 \% ostali troškovi i usluge (usluge sječe i izrade)

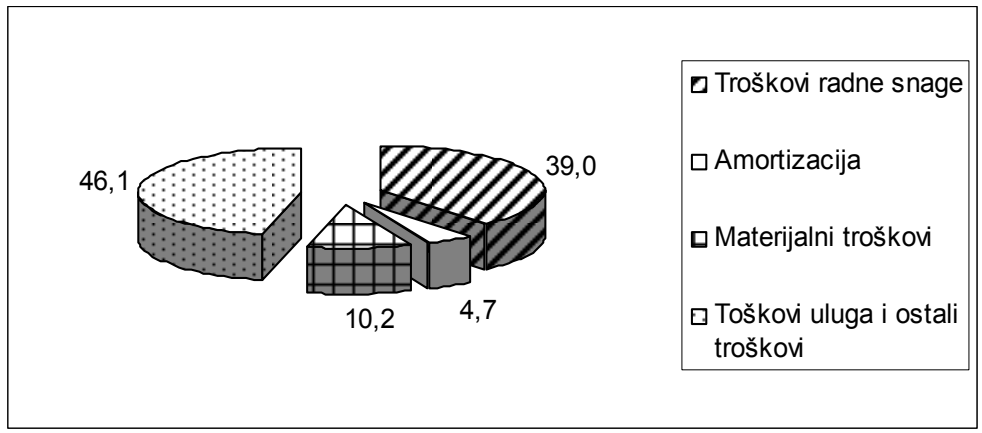

Grafikon 3. Struktura troškova poslovanja na nivou šumarstva Federacije BiH u 2006.g. Graph 3. Cost structure of B\&H Federation forestry, 2006.

Troškovi radne snage variraju po preduzećima i iznose od $27,7 \%$ do $51,5 \%$, troškovi amortizacije od $1 \%$ do $8 \%$. Ovi pokazatelj govore o različitom stepenu tehničke opremljenosti pojedinih preduzeća i različitom stepenu opterećenosti radnom snagom. I materijalni troškovi participiraju u različitom iznosu po pojedinim preduzećima. Troškovi usluga i ostali troškovi u sebi sadrže troškove sječe i izrade drvnih sortimenata, a preduzeća koja su ovu fazu privatizirala, obračunala su ove troškove kao usluge, te je ova stavka u strukturi troškova jako visoka. Struktura troškova po preduzećima je prikazana na grafikon 4 .

$\mathrm{Za}$ analizu su posebno bili interesantni troškovi iskorištavanja šuma i biološke reprodukcije po pojedinim preduzećima (tabela 3 ). U ove troškove su uračunati samo direktni troškovi, bez raspoređenog dijela opštih troškova. Kao što se vidi, direktni troškovi iskorištavanja na nivou Federacije iznose $21,77 \%$ od ukupnih troškova, uz variranje po preduzećima od $15 \%$ do $30 \%$. Osnovni razlozi za pojavu ovakvih razlika se mogu naći u načinu obračuna i obuhvatanja pojedinih troškova, načinu realizacije ove faze (sopstvena ili tuđa režija), ali svakako i zbog različitih uslova privređivanja. Dobiveni iznos troškova iskorištavanja po jedinici realizovane proizvodnje $\left(\mathrm{m}^{3}\right)$ su nerealno niski, te ne mogu biti osnov za komparaciju i donošenje zaključaka o stvarnim troškovima sječe i izrade. Komparacije radi, neka istraživanja ${ }^{5}$ su pokazala da prosječni troškovi sječe, izrade i izvoza šumskih drvnih sortimenata variraju od 26,70 do 42,76 KM $/ \mathrm{m}^{3}$. Očigledna razlika potvrđuje konstataciju da se kalkulacijama nisu obuhvatili svi troškovi.

\footnotetext{
${ }^{5}$ Završni izvještaj projekta Benchmarking u šumarstvu BiH , str. 36.
} 


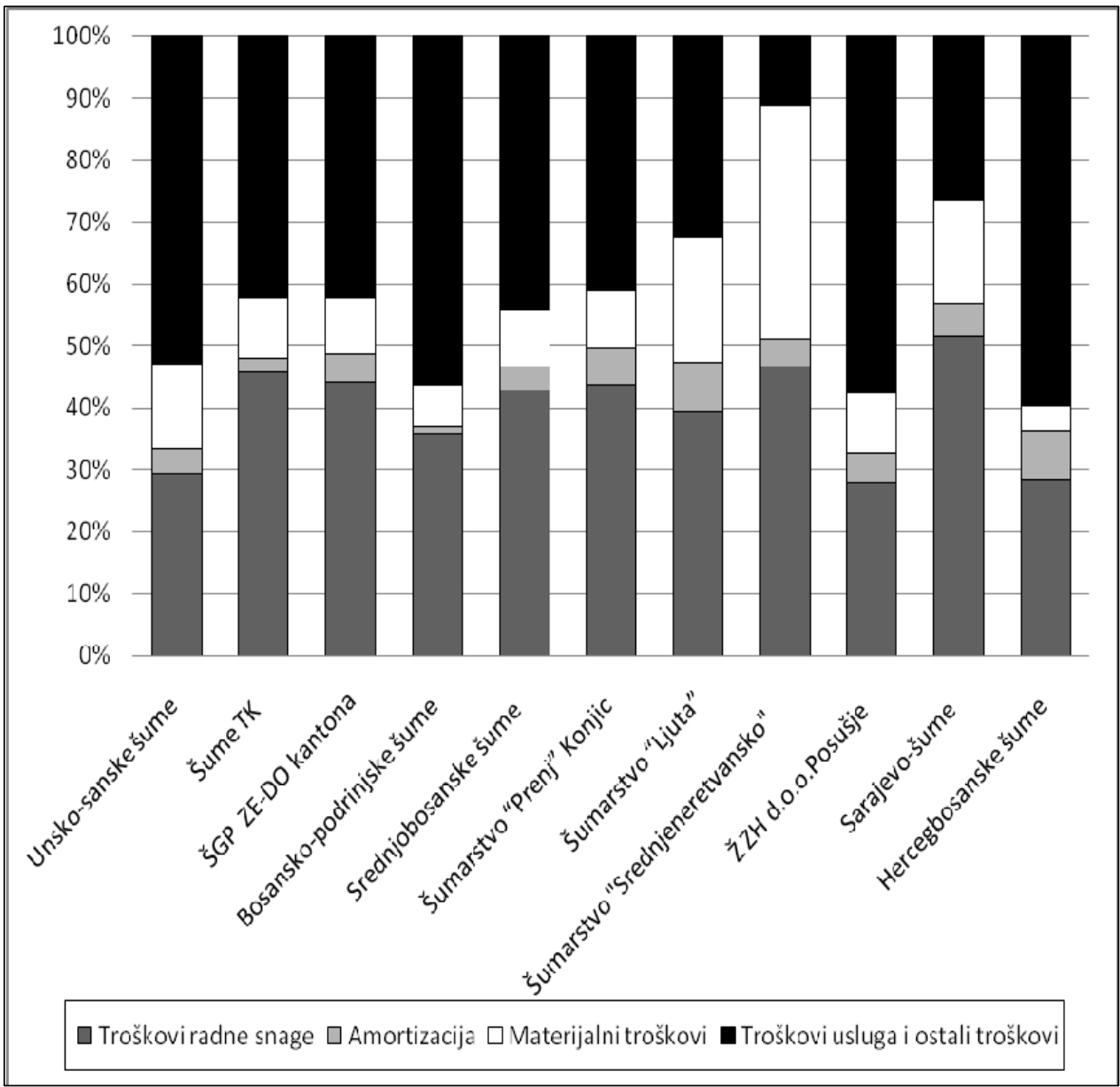

Grafikon 4. Struktura troškova poslovanja preduzeća šumarstva u Federaciji BiH u 2006. g. Graph 4. Costs structure of forestry enterpises in Federaton of B\&H, 2006.

Troškovi biološke reprodukcije (direktni troškovi šumskouzgojnih radova, troškovi izgradnje i rekonstrukcije šumskih kamionskih puteva) čine 11,75\% ukupnih troškova preduzeća šumarstva, što ukazuje na nizak obim radova iz područja biološke reprodukcije, posebno što oko $40 \%$ ovih troškova otpada na troškove izgradnje i rekonstrukcije puteva.

Prosječni troškovi biološke reprodukcije na nivou Federacije BiH iznose $11,6 \%$ od ukupnog prihoda, odnosno $14,5 \%$ prihoda od drveta. To znači da su izdvojena i utrošena sredstva u biološku reprodukciju manja od zakonski propisanog minimuma (6). Samo su neka preduzeća utrošila veći iznos od minimalno zakonski propisanog iznosa, tj. $15 \%$ prihoda od drveta za prostu reprodukciju i $3 \%$ za proširenu (grafikon 5). 
Tabela 3. Direktni troškovi sječe, izrade i izvoza i troškovi biološke reprodukcije Table 3. Direct costs of forest utilization and biological reproduction

\begin{tabular}{|l|r|c|c|r|c|}
\hline \multirow{2}{*}{$\begin{array}{c}\text { ŠUMSKOGOSPODARSKO } \\
\text { PREDUZEĆE }\end{array}$} & \multicolumn{2}{|c|}{ Ukupni troškovi sječe i izrade } & \multicolumn{2}{c|}{$\begin{array}{c}\text { Troškovi biološke } \\
\text { reprodukcije }\end{array}$} \\
\cline { 2 - 6 } & KM & $\begin{array}{c}\text { Učešće u } \\
\text { ukupnim } \\
\text { troškovima } \\
\%\end{array}$ & $\begin{array}{c}\text { Troškovi po } \\
\text { jedinici } \\
\text { proizvodnje } \\
\text { KM/m3 }\end{array}$ & KM & $\begin{array}{c}\text { Učěće u } \\
\text { ukupnim } \\
\text { troškovima \% }\end{array}$ \\
\hline Unsko-sanske šume & 9.967 .575 & 29,39 & 18,54 & 4.263 .063 & 12,57 \\
\hline Šume TK & 2.552 .614 & 15,76 & 10,36 & 2.448 .013 & 15,11 \\
\hline ŚGP ZE-DO kantona & 5.948 .345 & 17,83 & 13,31 & 2.435 .286 & 7,30 \\
\hline Bosansko-podrinjske šume & 231.741 & 17,29 & 6,00 & 266.722 & 19,90 \\
\hline Srednjobosanske šume & 8.188 .983 & 23,44 & 17,84 & 4.794 .187 & 13,72 \\
\hline Hercegovačko-neretvanski kanton & 1.275 .982 & 14,67 & 13,98 & 1.046 .805 & 12,03 \\
\hline Ž ZH d.o.o.Posušje & 144.000 & 25,84 & 16,61 & 219.500 & 39,38 \\
\hline Sarajevo-šume & 3.690 .881 & 19,67 & 21,07 & 4.001 .218 & 19,67 \\
\hline Hercegbosanske šume & 7.116 .083 & 23,47 & 12,06 & 1.441 .331 & 4,75 \\
\hline FEDERACIJA BIH & 39.116 .204 & 21,77 & 15,08 & 21.118 .377 & 11,75 \\
\hline
\end{tabular}

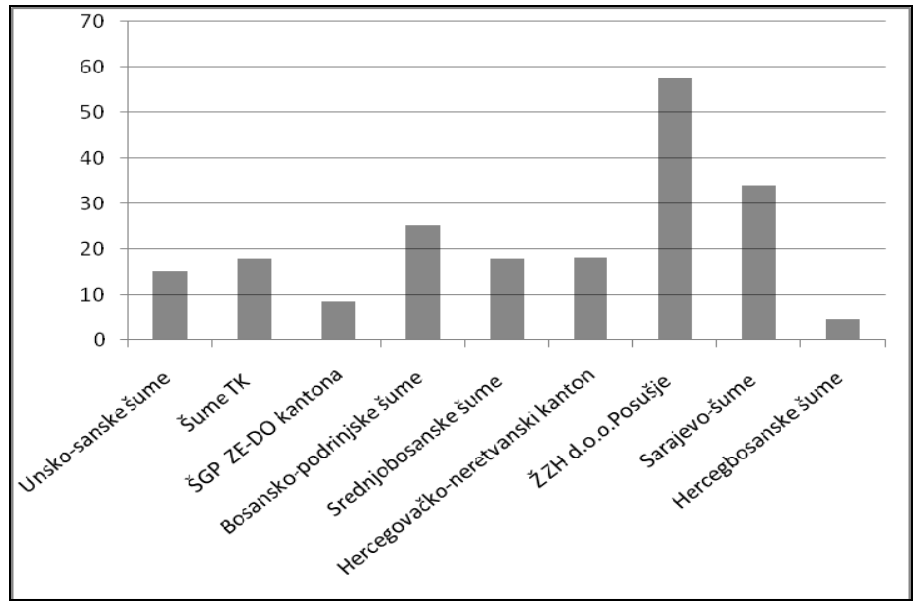

Grafikon 5. Učešće troškova biološke reprodukcije u ukupnom prihodu od drvnih sortimenata u pojedinim preduzećima (\%)

Graph 5. Share costs of biological reproduction in the revenue from forest wood productsin diferent enterprises (\%)

\subsection{Poslovni rezultat}

Kao neto rezultat svake proizvodnje na nivou preduzeća javlja se nova vrijednost koja se izražava kao dobit. Poslovni rezultat predstavlja razliku između ukupno ostvarenog prihoda $i$ utrošenih sredstava u proizvodnji tj. troškova proizvodnje (ŠunJIĆ-BEUS, 1999). U šumarstvu Federacije BIH je u 2006. godini ostvarena bruto dobit od 2,765 miliona KM. Preduzeća su ostvarila različite iznose dobiti, ili su poslovala negativno iskazujući gubitak (grafikon 6). 


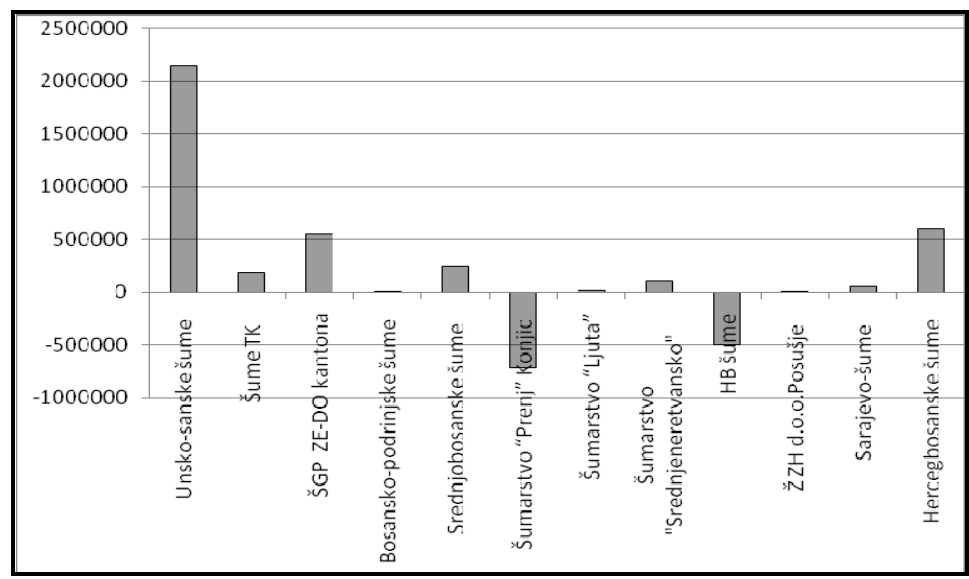

Grafikon 6. Rezultati poslovanja pojedinih preduzeća šumarstva u Federaciji BiH u 2006.g. (dobit/gubitak u KM)

Graph 6. Operating result of forest enterprises in Federation of B\&H, 2006.

Realni pokazatelji uspješnosti poslovanja (pored osnovnih ekonomskih principa; produktivnosti, ekonomičnost i i rentabilnosti) su npr. ostvarena dobit po zaposlenom ili ostvarena dobit po jedinici proizvodnje $\left(\mathrm{m}^{3}\right)$. Prosječno ostvarena dobit po zaposlenom u šumarstvu Federacije BiH iznosi 611,16 KM uz variranje od $60 \mathrm{KM}$ do 3,2 hiljade KM. Preduzeća koja su negativno poslovala ostvarila su gubitak od 4,6 hiljada, odnosno 7 hiljada KM po zaposlenom.

Prosječna dobit po $\mathrm{m}^{3}$ neto proizvedenog drveta iznosi $1,25 \mathrm{KM}$ na nivou Federacije. U tabeli 4. je dat prikaz ovih pokazatelja po preduzećima.

Tabela 4. Pokazatelji ostvarene dobiti

Table 4. Indikators of realised profit

\begin{tabular}{|c|c|c|c|c|c|}
\hline $\begin{array}{l}\text { ŠUMSKOGOSPODARSKO } \\
\text { PREDUZEĆE }\end{array}$ & $\begin{array}{c}\text { Rezultat } \\
\text { poslovanja } \\
\text { Dobit/gubitak } \\
\text { KM }\end{array}$ & $\begin{array}{c}\text { Broj } \\
\text { zaposlenih }\end{array}$ & $\begin{array}{c}\text { Dobit/gubitak } \\
\text { po } \\
\text { zaposlenom } \\
\text { KM/radniku }\end{array}$ & $\begin{array}{c}\text { Ostvarena } \\
\text { neto } \\
\text { proizvodnja } \\
\mathrm{m}^{3}\end{array}$ & $\begin{array}{c}\text { Dobit/gubitak } \\
\text { po m3 } \\
\text { proizvodnje } \\
\mathrm{KM} / \mathrm{m}^{3}\end{array}$ \\
\hline Unsko-sanske šume & 2.148 .922 & 662 & 3246,11 & 450.189 & 4 \\
\hline Šume TK & 177.396 & 533 & 332,83 & 204.712 & 0,87 \\
\hline ŠGP ZE-DO kantona & 553.040 & 1065 & 519,29 & 375.928 & 1,47 \\
\hline Bosansko-podrinjske šume & 2.457 & 40 & 61,43 & 32.585 & 0,08 \\
\hline Srednjobosanske šume & 247.590 & 1052 & 235,35 & 423.629 & 0,58 \\
\hline Šumarstvo "Prenj” Konjic & -717.784 & 156 & $-4601,18$ & 51.702 & $-13,88$ \\
\hline Šumarstvo "Ljuta" & 79.636 & 31 & 2568,90 & 7.637 & 10,43 \\
\hline $\begin{array}{l}\text { Sumarstvo } \\
\text { "Srednjeneretvansko" }\end{array}$ & 106.982 & 43 & 2487,95 & 10.783 & 9,92 \\
\hline HB šume & -499.857 & 72 & $-6942,46$ & 8.581 & $-58,25$ \\
\hline Ž ZH d.o.o.Posušje & 7.648 & 12 & 637,33 & 6.790 & 1,13 \\
\hline Sarajevo-šume & 58.891 & 379 & 155,39 & 145.981 & 0,40 \\
\hline Hercegbosanske šume & 600.557 & 480 & 1251,16 & 498.917 & 1,20 \\
\hline FEDERACIJA BIH & 2.765 .478 & 4525 & 611,16 & 2.217 .334 & 1,25 \\
\hline
\end{tabular}




\section{ZAKLJUČCI - Conclusions}

Šumarstvo Federacije svoj prihod uglavnom bazira na šumskim drvnim sortimentima, a mogućnost povećanja prihoda po osnovu iskorištavanja specijalnih šumskih proizvoda ili po osnovu razvoja drugih djelatnosti, gotovo se ne koristi i pored izuzetnih potencijala naših šuma. Zbog toga, cijene šumskih drvnih sortimenata i kvalitetna struktura etata imaju odlučujuću ulogu u formiranju ukupnog prihoda šumarstva.

Realizacija šumskih drvnih proizvoda u analiziranoj godini se uglavnom izvršila u skladu sa cijenama koje su definisane minimalnim cjenovnikom od strane preduzeća. Samo u nekim preduzećima je bila zastupljena prodaja putem licitacije, ali se radi o neznatnoj količini drvnih sortimenata. Cijene po cjenovniku za iste sortimente su različite po preduzećima i može se reći da su one iskustvene, a ne tržišne. To se na direktan način odražava na poslovni uspjeh.

S obzirom na to, može se zaključiti da se privređivanje u šumarstvu ne zasniva na integralnom i multifunkcionalnom korišćenju šumskih resursa, jer se:

- ne ostvaruju realno mogući prihodi po osnovu iskorišćavanja sekundarnih šumskih proizvoda, sekundarnih dijelova biomase (četine, sitna granjevina i dr.),

- privređivanje po osnovu lovstva nalazi na niskom nivou,

- ne ostvaruju prihodi po osnovu turističkih, rekreativnih i drugih socioloških i ekološko-zaštitnih funkcija šuma.

Preduzeća šumarstva u Federaciji $\mathrm{BiH}$ imaju različite uslove privređivanja (prirodne, materijalno-tehničke i ljudske resurse) iz kojih proizilaze i različite mogućnosti sticanja prihoda.

Obračun troškova se ne vrši po jedinstvenoj metodici, što stvara problem pri komparaciji. Struktura troškova poslovanja jako varira između preduzeća, što se direktno odražava na rentabilnost.

$\mathrm{U}$ analiziranoj godini je prosječna ostvarena dobit po jedinici proizvodnje $\left(\mathrm{m}^{3}\right)$ na nivou Federacije iznosila 1,25 KM, uz dijapazon variranja od 0,08 do $9,92 \mathrm{KM} / \mathrm{m}^{3} \mathrm{u}$ pojedinim preduzećima, dok je gubitak u preduzećima koja su negativno poslovala iznosio $13,88 \mathrm{KM}$, odnosno $58,25 \mathrm{KM}$ po $\mathrm{m}^{3}$ proizvedenog drveta. Zato je i akumulativna $\mathrm{i}$ reproduktivna sposobnost preduzeća na različitom nivou. Iz ovog proizlazi da se u pojedinim situacijama država kao vlasnik resursa, ne bi trebala osloniti na materijalne mogućnosti preduzeća kada su u pitanju investiranja u biološku reprodukciju. U protivnom, moglo bi doći do narušavanja principa kontinuiteta gospodarenja šumskim resursima.

\section{Zahvala - Acknowledgement}

Ovaj rad je dio rezultata istraživanja u okviru projekta „Istraživanje cijene gospodarenja šumama i šumskim zemljištem na području Federacije $\mathrm{BiH}^{\text {“, }}$ koji je finansiran od strane Federalnog ministarstva poljoprivrede, vodoprivrede i šumarstva, na čemu se ovom prilikom zahvaljujemo. 


\section{LITERATURA - Literature}

DELIĆ, S. (2006): Istraživanje modela finansiranja biološke reprodukcije u šumarstvu Bosne i Hercegovine, doktorska disertacija, Šumarski fakultet, Sarajevo

Delić, S: (2008): Biological Reproduction in forestry in Bosnia and Herzegovina Practical issues of the forest law, (in press)

MARTINIĆ, I. (1996): Ekonomski i organizacijski kriteriji za oblikovanje šumskih radova, Glasnik za šumske pokuse, Vol. 33. str. 215-299, Zagreb,

ŠAKOVIĆ, Š. (1998): Neke ekonomske karakteristike proizvodnje u šumarstvu kao osnovice za formulaciju šumarske politike

ŠunJić - Beus, M., Berberović, Š., STAVRIĆ, B. (1999): Ekonomika preduzeća, Ekonomski fakultet, Sarajevo

Plan rada i poslovanja za 2006. godinu preduzeća šumarstva u Federaciji BiH

Izvještaji o poslovanju preduzeća za period januar-decembar 2006. godine,

Zakon o šumama (2002): Službene novine Federacije BiH

Završni izvještaj projekta Benchmarking u šumarstvu BiH

\section{SUMMARY - Sažetak}

The results of this analysis show that Forest Management Companies (FMCs) in the Federation of B-H, obtain $80 \%$ of their revenues from wood assortments production. Only $20 \%$ of their revenues come from non-wood forest products and other sources. This clearly points out that forestry in the Federation of B-H is not based on the principles of multifunctional management of forest resources.

Having in mind the differences in production conditions among Forest Management Companies (FMCs), the structure of their costs varies also. For instance, the share of labour costs in different FMCs varies between 27,7\% and 51,5\%. As concerns the costs of utilization as well as the costs of biological reproduction, there are also significant differences. These differences are not caused merely by different production conditions but also by the way how the specific types of costs are calculated. The financial assets allocated for biological reproduction amount 14,5\% of realized revenue what is less then the legally prescribed minimal rate.

The different cost and revenue structure has direct implications on Forest Management Companies' business results but also to their accumulative and reproductive capabilities. Current planning of biological investments is mainly based on Forest Management Companies' financial possibilities. As they are not planed according to the real need, such a forest investment policy is not sustainable. The implications on forest resources might be very serious and this is what the Federation of $\mathrm{B}-\mathrm{H}$ as the owner should take into account. 